\title{
Non-invasive Instrument-based Tests for Quantifying Anterior Chamber Flare in Uveitis: A Systematic Review
}

Xiaoxuan Liu'², Thomas McNally², Sophie Beeses, Laura E Downie ${ }^{4}$, Ameenat L Solebos,, Livia Faes, ${ }^{6,7}$, Syed Husain², Pearse A Keane, David J Moore ${ }^{3}$, Alastair K Denniston ${ }^{12.6,8}$

${ }^{1}$ Ophthalmology Department, University Hospitals Birmingham NHS Foundation Trust, Birmingham, UK

${ }^{2}$ Academic Unit of Ophthalmology, Institute of Inflammation \& Ageing, College of Medical and Dental Sciences, University of Birmingham, UK

3Institute of Applied Health Research, College of Medical and Dental Sciences, University of Birmingham, UK

${ }^{4}$ Department of Optometry and Vision Sciences, The University of Melbourne, Parkville, Victoria, Australia

5Institute of Child Health, University College London, London, UK

${ }^{6}$ NIHR Biomedical Research Centre for Ophthalmology, Moorfields Eye Hospital NHS Foundation Trust and UCL Institute of Ophthalmology, UK

${ }^{7}$ Eye Clinic, Cantonal Hospital of Lucerne, Spitalstrasse, 6000 Lucerne, Switzerland.

8Health Data Research UK, London, UK

Corresponding author: Prof Alastair Denniston, Academic Unit of Ophthalmology, Institute of Inflammation \& Ageing, College of Medical and Dental Sciences, University of Birmingham, UK. Email: a.denniston@bham.ac.uk 


\section{Abstract}

Purpose: Anterior chamber (AC) flare is a key sign for anterior uveitis. New instrumentbased techniques for measuring AC flare can offer automation and objectivity. This review aims to identify objective instrument-based measures of $A C$ flare.

Methods: In this systematic review, we identified studies reporting correlation between instrument-based tests versus clinician AC flare grading, and/or aqueous protein concentration, as well as test reliability.

Results: Four index tests were identified in 11 studies: laser-flare photometry (LFP), optical coherence tomography, ocular flare analysis meter (OFAM) and the double-pass technique. The correlation between LFP and clinician grading and protein concentration was $0.40-0.93$ and 0.87-0.94, respectively. The double-pass technique showed no correlation with clinician grading and insufficient information was available for OFAM.

Conclusion: LFP shows moderate to strong correlation with clinician grading and aqueous protein concentration. LFP could be a superior reference test compared to clinician AC flare grading for validating new index tests.

\section{Keywords}

Systematic review, uveitis, anterior chamber flare, aqueous humor, aqueous humour, Tyndall effect, diagnostic test, aqueous protein concentration, optical coherence tomography, laser flare photometry. 


\section{Introduction}

Anterior uveitis describes inflammatory mediated breakdown of the blood-aqueous barrier with resultant leakage of blood constituents into the aqueous humour. Clinically this is predominantly characterised by anterior chamber (AC) cells and flare. AC flare is an important clinical marker of inflammation, and has been shown to be the predominant sign in syndromes such as childhood chronic anterior uveitis.1.2 To measure the true extent of blood-aqueous barrier breakdown requires sampling of the aqueous humour through paracentesis using a needle inserted into the AC, and measurement of the protein concentration in that sample. Whilst this invasive test provides the most accurate quantification of aqueous constituents, it is not feasible for repeated measurement in the context of disease monitoring. The more common approach is to observe this change using slit lamp biomicroscopy, as 'flare', an appearance of haziness of the aqueous humour. Flare can be graded using semi-quantitative scales, of which the Standardization of Uveitis Nomenclature (SUN) grading system is most commonly used. ${ }^{3}$ The SUN system measures flare according to the observer's ability to visualise details of the iris and lens behind the aqueous. Grades range from 0 , which corresponds to no visible flare, to +4 , which corresponds to intense flare (Table 1). Although this clinician-based method is subjective,,$^{4}$ quantifying aqueous inflammation this way is widely accepted as a clinical standard and is used to inform treatment decisions. 5 It is recognised that non-invasive and objective methods for measuring aqueous inflammatory change would significantly improve clinical assessment of anterior uveitis.

Instrument-based techniques such as laser flare photometry (LFP) have been available for the last 20 years but have not been widely adopted. This is despite the evidence supporting the validity and clinical utility of LFP. techniques such as anterior segment optical coherence tomography (AS-OCT) have also demonstrated the potential to quantify AC flare.10 Given the need for an objective non-invasive method for assessing aqueous inflammation, a systematic examination of the evidence of such technologies is timely. 11 This review aims to identify all instrumentbased tools for measuring aqueous humour inflammation in uveitis and evaluate their 
correlation with laboratory measurements of aqueous protein concentration and/or slitlamp based clinician grading systems.

\section{Table 1: The Standardisation of Uveitis Nomenclature (SUN) working group grading scheme for anterior chamber flare. ${ }^{3}$}

\begin{tabular}{lll}
\hline Grade & Flare & Description \\
\hline $\mathbf{0}$ & None & No alteration to iris and lens visualization \\
\hline $\mathbf{1 +}$ & Faint & Barely detectable \\
\hline $\mathbf{2 +}$ & Moderate & Iris and lens details clear despite discernible haze \\
\hline $\mathbf{3 +}$ & Marked & Iris and lens details hazy \\
\hline $\mathbf{4 +}$ & Intense & Fixed coagulated aqueous with considerable fibrin \\
\hline
\end{tabular}

Standardization of uveitis nomenclature for reporting clinical data. Results of the First International Workshop. Jabs DA, Nussenblatt RB, Rosenbaum JT. 2005.

\section{Methods}

This review is reported according to the Preferred Reporting Items for Systematic Reviews and Meta-Analysis (PRISMA) statement.12 The methodology was specified in advance and the protocol registered with PROSPERO (CRD42017084167).13 The primary aim of this review was to evaluate all non-invasive, instrument-based methods for measuring aqueous humour inflammation and their level of correlation with, 1) the gold standard reference test: analysis of protein concentration in aqueous samples, and/or 2) the clinical reference test: slit-lamp based AC flare grading performed by a clinician. We accepted both as reference tests in recognition that aqueous paracentesis is rarely performed, and clinician grading is widely used as the basis for final clinical 
decision-making in practice. A secondary aim was to identify studies which also reported the reliability of index tests and compare the reliability between different tests.

\section{Search strategy}

We combined free text terms and index terms reflecting the pathological finding of interest, 'flare' or 'proteins' and 'anterior chamber' or 'aqueous humor', and the disease context 'uveitis' or 'inflammation' (search strategy available in Supplementary Materials). Database searches were carried out in MEDLINE, Embase, Cochrane Controlled Register of Trials (CENTRAL), Centre for Reviews and Dissemination Database (Health Technology Assessments and the Database of Abstracts and Reviews of Effects), Clinicaltrials.gov, WHO International Clinical Trials Registry Platform (ICTRP portal), British Library's ZETOC, Conference Proceedings Citation Index (Web of Science), British Library Ethos, ProQuest and OpenGrey. We searched all databases from inception to 07 August 2019, with no date or language restrictions. We manually searched citations of review articles and included studies to identify additional relevant articles.

\section{Study selection}

Two reviewers independently assessed study eligibility, and disagreements were resolved through consensus, or referral to a third reviewer if needed. Studies were eligible if they described one or more instrument-based methods for measuring aqueous humour protein levels (index test) and compared its measurements to actual aqueous protein concentration and/or clinician grading (reference tests). We also included studies reporting test reliability. The primary outcome of interest was the level of correlation between index tests and either of the two reference tests. The secondary outcome was intra/inter-observer reliability of the index test. We did not exclude studies based on subject age, gender, ethnicity, underlying aetiology or disease activity status. Animal studies and studies involving only healthy participants, single case reports, commentaries and opinion articles were excluded.

\section{Data extraction}


Two reviewers independently extracted data using a pre-specified data extraction sheet. Two texts were translated from Chinese into English. We contacted two authors for further information and both responded. . $1.15_{\text {If }}$ only individual patient data were reported, we used this information to calculate the correlation coefficient.

\section{Risk of Bias assessment}

Two reviewers independently assessed the risk of bias, in studies comparing correlation between two tests, using a modified version of the Quality Assessment of Diagnostic Accuracy Studies tool (QUADAS-2).16 We pre-specified adaptations to the original QUADAS-2 signalling questions to address the review question. For example, one signalling question was added in the index test section on whether index test protocols were determined a priori and standardised for all participants.

\section{Data analysis}

For each outcome, studies were grouped by the reference test against which comparisons were made: aqueous protein concentration or clinician grading. For each index test, we tabulated the extracted information and provided a narrative synthesis of methodological characteristics and index tests evaluated. Where confidence intervals for correlation coefficients were not reported, we estimated them using sample size and correlation coefficient and presented this on a forest plot. All statistical analyses were performed using Stata Statistical Software (Release 15. College Station, TX: StataCorp LP.)

\section{Results}

\section{Results of the Search}

The study selection process is summarised in the PRISMA flow diagram (Figure 1). The search yielded 3741 unique bibliographic records after removal of duplicates. Of these, 3629 were excluded based on screening of titles and abstracts. The large number of excluded articles is owing to the unrestrictive nature of our search strategy, which was deliberately designed to not include any index test terms, to ensure full 
capture of all relevant studies. The remaining 110 articles were obtained in full text for further scrutiny and a further 99 articles were excluded. The reasons for exclusion were due to not matching the criteria for outcome $(n=52)$, population $(n=24)$, study design $(n=19)$ and for the lack of an appropriate reference test $(n=4)$. Eleven unique studies met the eligibility criteria and were included (Table 2).

\section{Participants' Characteristics and Study Design Features}

The 11 studies included a total of 876 participants (at least 1016 eyes; one study did not report the number of eyes 1 ), and dated from 1989 to 2017.10 .1726 Study characteristics are summarised in Table 2. One study used retrospectively collected routine clinical care data ${ }^{19}$, whilst all other studies collected data prospectively. Gender was reported in 8 of the 11 studies, $44 \%$ of participants $(n=360)$ were male. Age was reported in 8 of the 11 studies $10.171 .9-2.2426$, ranging from 12 to 86 years. Three studies included mixed etiologies, including sarcoidosis, Behcet's disease, Vogt-Koyanagi Harada disease, acute retinal necrosis, lyme disease, progressive outer retinal necrosis, retinal vasculitis, herpes zoster ophthalmicus and FHC. ${ }_{171823}$ Five studies did not report specific uveitis entities and instead reported anatomical classification or disease activity (active, inactive and healthy controls). 10222426 Two studies did not report any aetiological classifications. ${ }^{20221}$ One study included only eyes with Fuch's Heterochromic Cyclitis (FHC).19

\section{Methodological Quality of the Included Studies}

A summary of the risk of bias assessment for the included studies is presented in Supplementary Figure 1. Eight out of eleven studies did not report how subjects were recruited into the study $1-2-2,23-26$ and had an unclear risk of bias regarding participant selection. Given the known limitations of the clinician grading system, all studies which utilised clinician grading as the reference test $(n=8)$ were marked as unclear due to concerns around disease misclassification. It was unclear in 5 studies 1 1-2.2.24 whether the index test was interpreted without knowledge of the reference tests and vice versa. One study was identified as having a high risk of bias for patient flow as readings were unsuccessful in 31 of the 121 included subjects. 21 Another study had high applicability concerns as the entire patient cohort was eyes with $\mathrm{FHC} .19$ 


\section{Clinical reference test: slit-lamp based clinician grading}

Nine out of 11 studies $\frac{101719-222426}{2}$ compared an index test with AC flare grading based upon clinician slit-lamp examination. Six studies $10.19-2224$ used the SUN grading system and 3 studies ${ }_{1725}$ did not specify a standardised grading system. Six studies reported the number of eyes at each AC flare grade. 10202212426 Three of these studies included patients in all 4 grades of severity, 2 studies had eyes with each grade except grade 4 , and 1 study included eyes with grades 0.5 and grade 1 of AC flare only. Three studies did not report the number of patients in each grade of $A C$ flare. ${ }^{1721}$

\section{Laboratory reference test: aqueous protein concentration}

Three out of 11 studies compared an index test with aqueous protein concentration. .182324 Two studies 2.2 .24 used paracentesis samples taken from individuals with uveitis prior to routine cataract surgery, one study $\stackrel{18}{ }$ used diagnostic paracentesis samples for eyes with

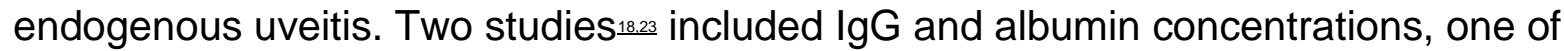
which also measured total protein, and the other study $\_$did not specify which proteins were measured.

\section{Instruments for measuring AC cells}

Four different classes of index tests that fit the description of non-invasive imaging techniques were identified. The majority of studies evaluated the use of LFP (9 studies). LFP devices included various models produced by KOWA, including the FC-1000, FC$2000, F C-500$ and the only two models which are currently commercially available, the FM-600 and FM-700. Most studies reported taking between 3-7 repeated measurements at each observation and taking the averaged value, as is the usual procedure according to LFP instructions. The sampling volume was reported as $0.075 \mathrm{~mm}^{3}$ for the FC-1000 (mean anterior chamber volume being approximately $145 \mathrm{~mm}^{3}$ )ㄹ and sampling area was reported to be $0.3 \mathrm{~mm}$ by $0.5 \mathrm{~mm}$ for the FC-2000, FC600 and FC-700. All measurements were derived using the built-in software of the LFP. One study evaluated a swept-source OCT device (Casia SS-1000, Tomey Corporation, Japan), taking two $6 \mathrm{~mm}$ cross-sectional scans in the anterior chamber. The AS-OCT images were then used to derive an image brightness ratio between the aqueous and 
air anterior to the cornea, using custom software, producing an 'aqueous-to-air' relative intensity (ARI).10 One study used a custom-built ocular flare analysis meter (OFAM) 21 and one study used an optical quality analysis system (OQAS II, Visionmetrics, Terrassa, Spain) based on the double-pass technique, a technique measuring the amount of ocular scatter caused by the presence of flare.22

\section{Index test reliability}

Only two studies reported index test reliability. Invernizzi et al. reported an intraclass correlation of 0.78 for the OCT-derived ARI index measurement, and Shah et al. reported a coefficient of variation of $7.3 \%$ for the Kowa FC-1000 LFP. Nanavaty et al. performed a reproducibility study, however these were on healthy pseudophakic eyes, rather than uveitis eyes.

\section{Correlation between index tests and the clinical reference test: slit-lamp based clinician grading}

Six studies reported correlation between an index test and clinician grading of AC flare (five studies using the LFP and one study using the optical quality analysis system).171922242626 The total number of eyes included in these six studies was 478 . Various statistical methods including Kendall's, Spearman's and Pearson's correlation coefficients were used. The level of correlation between the LFP and clinician grading ranged from $0.40-0.93$. The one study using the optical quality analysis system reported a Pearson's r of 0.0048. Although the OFAM and OCT devices were compared against SUN grading, no correlation coefficient was reported.

\section{Correlation between index tests versus the laboratory reference test: aqueous protein concentration}

Three studies reported correlation between an index test and aqueous protein concentration, all of which used LFP as the index test. ${ }_{102324}$ Shah et al and Shoughy et al included non-uveitic eyes in the correlation analysis, whereas Chiou et al included eyes with endogenous uveitis only. The total number of eyes included across all three studies was 59. One study $\underline{23}$ calculated a Pearson's $r$ and another study ${ }^{18}$ did not report which statistical test was used. In the last study, individual patient data was reported so we 
derived the correlation between the two tests for uveitic eyes using Pearson's $r$. ${ }^{24}$ The level of correlation between index test measurements and protein concentrations ranged from $0.87-0.99$. From the limited data, there were no apparent associations between type of protein and level of correlation.

The forest plot showing correlation between LFP and the two reference tests: clinician grading and aqueous protein concentration is shown in Figure 2. None of the included studies reported confidence intervals to correlation coefficients and those shown in the forest plot were estimated using sample size and correlation coefficient.

\section{Study Heterogeneity}

There was considerable heterogeneity between the methodology and populations across the included studies. These characteristics were wide ranging particularly in regard to the various device models used, the distribution of disease subtype and severity, and the statistical tests used to calculate correlation. Given this level of heterogeneity, any meta-analysis of correlation coefficients for would be inappropriate.

\section{Figure 2. Level of correlation between LFP and clinician grading and aqueous protein concentration}

\section{Discussion}

This is the first systematic review evaluating all non-invasive instrument-based tests for quantifying aqueous humour inflammation. We found four non-invasive index tests: OCT, LFP, OFAM and the Double Pass technique (using the OQAS). Of all the index tests, we found LFP to have the strongest evidence base, with good correlation with clinician grading and very good correlation with aqueous sample protein concentration. However, only a small number of studies provided sufficient information to support this finding and incomplete reporting and inconsistent methodology of included studies meant we were unable to pool estimates of correlation between index and reference tests. 
Our review found a strong correlation between the LFP and clinician grading of AC flare, as well as aqueous protein concentration, in most studies. There was no apparent relationship between the device model and level of correlation, and the current available model (FM-600) validated in one study, was reported to have good correlation ( $r=0.86$ - 0.87) with clinician grading. An interesting finding was that LFP measurements showed a stronger correlation with protein concentration $(r=0.87-0.99)$ than with clinician grading $(r=0.40-0.93)$. If aqueous paracentesis was assumed to be the true gold standard, then this finding would suggest LFP is a more accurate marker of aqueous protein levels than clinician grading. Shoughy et al. was the only study which reported all three methods at the individual eye level, allowing us to calculate correlation between all three methods. Their measurements showed a higher correlation between aqueous protein concentration and LFP $(r=0.99)$ than aqueous protein concentration and clinician grading $(r=0.93)$, however this is based on only ten eyes (five of which were grade 0 by SUN grading).

The OFAM is a new device utilising the Rayleigh scattering effect with a theoretically higher sensitivity to smaller molecules than the Tyndall effect used by LFP. Although the authors report significant differences in OFAM measurement in eyes with grade 1 and 2, when compared with grade 0 , the device could not differentiate between grades 1 and 2. The double pass technique using the OQAS showed poor correlation with AC flare grading, but the authors reported a significant correlation with AC cells $(r=0.87)$ and significantly more ocular scatter in eyes with anterior uveitis than intermediate and posterior subtypes.

Invernizzi et al reported the only evaluation of OCT for quantifying AC flare. Although they did not report a correlation coefficient between OCT or LFP compared against clinician grading, they showed that OCT derived ARI index significantly increased with each grade of AC flare. Similarly, LFP readings in their study significantly increased with each grade of $A C$ flare, with the exception of grade 0 to grade 1 . When comparing the two index tests, LFP and ARI index, they found a moderate correlation $(r=0.61)$. OCT has the added advantage of sampling a larger theoretical volume of AC compared to LFP and is fast and convenient to acquire. Additionally, the counting of AC cells using anterior segment OCT has been described by Invernizzi et al and others and has been 
shown to be an automatable process. Therefore, OCT has the added advantage of offering a comprehensive all-in-one multi-faceted assessment of $A C$ inflammation. 2

\section{Strengths and limitations of the review}

This review represents the first systematic evaluation of technologies for measuring $A C$ flare or aqueous inflammation. Previous reviews have summarised the level of validation for LFP, however this is the first review to consider all technologies, including newer imaging modalities such as OCT. Our search strategy was designed to be highly sensitive and included a broad range of databases, including conference proceedings, dissertation databases and the grey literature. However, our review also has a number of limitations. We only included studies reporting correlation between tests or reliability of tests, therefore any other methods of test comparison (such as those demonstrating significant difference in index test measurements across SUN grades) were not included. This is because our original intention was to choose a commonly reported metric which would enable comparison between index tests. Whilst correlation is useful, it is limited to demonstrating agreement and non-inferiority to the comparator. From correlation, it is not possible to determine if the index test is more accurate than the reference test. This is an important consideration when the clinician grading system is the reference test, where the index test may in fact provide a more accurate measurement.

\section{Limitations of the evidence}

First, due to the small number of included studies and heterogeneity in study design, it was not possible to provide pooled estimates of correlation or reliability. Second, authors sometimes reported correlation coefficients estimated from a mixed cohort of uveitic and healthy eyes. Where the two groups could be separated, or where individual patient data was available, we extracted and calculated correlation coefficients from uveitic eyes only. However, this was not possible in all studies and non-uveitic eyes were included in the original analysis as grade 0 . Third, in two studies correlation was derived from eyes with two clinical grades of AC flare only (i.e. SUN grade 1 and grade 2 only). In these cases, there is an applicability concern around whether the study 
population adequately represents the target population and the correlation coefficient is also less meaningful.

\section{Clinical relevance and impact}

Anterior chamber flare is an important measure in the assessment of uveitic inflammation. This review finds that instrument-based tools such as the LFP can achieve good agreement with widely accepted clinical and laboratory reference tests and may be a more accurate marker of true aqueous protein concentration than clinical grading. Despite being available for some time, the LFP has not been widely adopted in clinical care. This may be due to practical reasons, as using the LFP involves taking up to seven readings with a degree of manual input, including discarding spurious readings and computing an average value. Additionally, the LFP is sensitive to ambient lighting and therefore requires a completely dark room, and acquisition can be more difficult for eyes with posterior synechiae and a shallow AC. Such practical considerations may outweigh the added clinical value of such a device. However, we would argue that in a clinical trial context, accuracy and reliability should take precedence and the LFP could be adopted in place of $\mathrm{AC}$ flare grading.

We would also suggest that for the validation of newer imaging methods, the LFP may be a more appropriate reference test in comparison to clinician grading, when aqueous protein concentration is not available. However, this is based on findings from a small number of eyes in a single study. We would suggest that a well-conducted study on a larger cohort of eyes, comparing AC flare grading using the slit-lamp, aqueous paracentesis and LFP, would be helpful for confirming whether LFP can replace clinician grading as the clinical reference test.

\section{Conclusion}

Instrument-based tests have the potential to offer more objectivity to measurements of AC inflammation compared to the widely used clinician grading using slit-lamp. The validation of LFP is the most mature for this purpose and has shown strong correlation with clinician grading of $A C$ flare and more importantly with aqueous protein concentrations. Although LFP may not be widely adopted in clinical practice, it may 
have value as a non-invasive reference test with which to validate emerging technologies for measuring AC flare.

\section{Disclosure of interest}

AKD and PAK receive a proportion of their funding from the Department of Health's NIHR Biomedical Research Centre for Ophthalmology at Moorfields Eye Hospital and UCL Institute of Ophthalmology. XL and AKD receive a proportion of their funding from the Wellcome Trust, through a Health Improvement Challenge grant (200141/Z/15/Z). ALS is supported by an NIHR Clinician Scientist award (CS-2018-18-ST2-005). LED has no disclosures relating directly to this work. She has received research funding from Allergan Pty Ltd, Alcon Pty Ltd and Azura Ophthalmics, and consulting income from Seqirus and Medmont International, outside of this work.

\section{Author Contributions}

XL: lead reviewer, manuscript drafting, manuscript reviewing. TWM: second reviewer, data extraction manuscript drafting, manuscript reviewing. SB: data extraction, manuscript drafting, manuscript reviewing. LF, LD, ALS, SH: manuscript drafting, manuscript reviewing. PAK, DJM, AKD project conception, supervision, manuscript reviewing. 


\section{References}

1. Holland GN. A reconsideration of anterior chamber flare and its clinical relevance for children with chronic anterior uveitis (an American Ophthalmological Society thesis). Trans Am Ophthalmol Soc. 2007;105:344.

2. Davis JL, Dacanay LM, Holland GN, Berrocal AM, Giese MJ, Feuer WJ. Laser flare photometry and complications of chronic uveitis in children. Am J Ophthalmol. 2003;135(6):763-771.

3. Jabs DA, Nussenblatt RB, Rosenbaum JT, Group S of UN (sun) W. Standardization of uveitis nomenclature for reporting clinical data. Results of the First International Workshop. Am J Ophthalmol. 2005;140(3):509-516.

4. Agrawal R, Keane PA, Singh J, Saihan Z, Kontos A, Pavesio CE. Comparative Analysis of Anterior Chamber Flare Grading between Clinicians with Different Levels of Experience and Semi-automated Laser Flare Photometry. Ocul Immunol Inflamm. 2016;24(2):184-193.

5. Kempen JH, Ganesh SK, Sangwan VS, Rathinam SR. Interobserver Agreement in Grading Activity and Site of Inflammation in Eyes of Patients with Uveitis. Am J Ophthalmol. 2008;146(6):813-818.

6. Herbort CP, Tugal-Tutkun I. The importance of quantitative measurement methods for uveitis: laser flare photometry endorsed in Europe while neglected in Japan where the technology measuring quantitatively intraocular inflammation was developed. Int Ophthalmol. 2017;37(3):469-473.

7. Sawa M. Laser flare-cell photometer: principle and significance in clinical and basic ophthalmology. Japanese Journal of Ophthalmology. 2017;61(1):21-42. doi:10.1007/s10384016-0488-3

8. Tappeiner C, Heinz C, Roesel M, Heiligenhaus A. Elevated laser flare values correlate with complicated course of anterior uveitis in patients with juvenile idiopathic arthritis. Acta Ophthalmol. 2011;89(6):e521-e527.

9. Bernasconi O, Papadia M, Herbort CP. Sensitivity of laser flare photometry compared to slitlamp cell evaluation in monitoring anterior chamber inflammation in uveitis. Int Ophthalmol. 2010;30(5):495-500. 
10. Invernizzi A, Marchi S, Aldigeri R, et al. Objective Quantification of Anterior Chamber Inflammation: Measuring Cells and Flare by Anterior Segment Optical Coherence Tomography. Ophthalmology. 2017;124(11):1670-1677.

11. Denniston AK, Keane PA, Srivastava SK. Biomarkers and Surrogate Endpoints in Uveitis: The Impact of Quantitative Imaging. Invest Ophthalmol Vis Sci. 58(6):BIO131-BIO140.

12. Moher D, Liberati A, Tetzlaff J, Altman DG, PRISMA Group. Preferred reporting items for systematic reviews and meta-analyses: the PRISMA statement. Int J Surg. 2010;8(5):336-341.

13. Liu X, Moore D, Denniston AK. PROSPERO Instrument-based tests for measuring anterior chamber (AC) flare in uveitis: a systematic review. PROSPERO. doi:https://www.crd.york.ac.uk/prospero/display_record.php?RecordID=84167

14. Oshika T, Nishi M, Mochizuki M, et al. Quantitative assessment of aqueous flare and cells in uveitis. Jpn J Ophthalmol. 1989;33(3):279-287.

15. Tugal-Tutkun I, Cingü K, Kir N, Yeniad B, Urgancioglu M, Gül A. Use of laser flare-cell photometry to quantify intraocular inflammation in patients with Behet uveitis. Graefes Arch Clin Exp Ophthalmol. 2008;246(8):1169-1177.

16. Whiting PF, Rutjes AWS, Westwood ME, et al. Quadas-2: A revised tool for the quality assessment of diagnostic accuracy studies. Ann Intern Med. 2011;155(8):529-536.

17. Ohara K, Okubo A, Miyazawa A, Miyamoto T, Sasaki H, Oshima F. Aqueous flare and cell measurement using laser in endogenous uveitis patients. Jpn J Ophthalmol. 1989;33(3):265270.

18. Chiou AG, Florakis GJ, Herbort CP. Correlation between anterior chamber lgG/albumin concentrations and laser flare photometry in eyes with endogenous uveitis. Ophthalmologica. 1998;212(4):275-277.

19. Fang $W$, Zhou $H$, Yang $P$, Huang $X$, Wang L, Kijlstra A. Aqueous flare and cells in Fuchs syndrome. Eye. 2009;23(1):79-84.

20. Konstantopoulou K, Del???Omo R, Morley AM, Karagiannis D, Bunce C, Pavesio C. A comparative study between clinical grading of anterior chamber flare and flare reading using the Kowa laser flare meter. Int Ophthalmol. 2015;35(5):629-633. 
21. Lam DL, Axtelle J, Rath S, et al. A Rayleigh Scatter-Based Ocular Flare Analysis Meter for Flare Photometry of the Anterior Chamber. Trans/ Vis Sci Technol. 2015;4(6):7.

22. Nanavaty MA, Stanford MR, Sharma R, Dhital A, Spalton DJ, Marshall J. Use of the doublepass technique to quantify ocular scatter in patients with uveitis: A pilot study. Ophthalmologica. $2010 ; 225(1): 61-66$.

23. Shah SM, Spalton DJ, Taylor JC, et al. Correlations between laser flare measurements and anterior chamber protein concentrations. Invest Ophthalmol Vis Sci. 1992;33(10):2878-2884.

24. Shoughy SS, Elkum N, Tabbara KF. Aqueous protein level and flare grading. Acta Ophthalmol. 2015;93(2):e173-e174.

25. Yang $\mathrm{P}-\mathrm{Z}$, Wang $\mathrm{H}$, Huang $\mathrm{X}-\mathrm{K}$, et al. [Quantitative determination of aqueous flare and cells in the eyes of patients with inflammation of anterior uvea]. Zhonghua Yan Ke Za Zhi. 2004;40(8):510-513.

26. Zhou Y, Jing X-H, Li X-Y. Application value of laser flare cell meter in uveitis. Guoji Yanke Zazhi. 2013;13(9):1775-1777.

27. Wang N, Wang B, Zhai G, Lei K, Wang L, Congdon N. A method of measuring anterior chamber volume using the anterior segment optical coherence tomographer and specialized software. Am J Ophthalmol. 2007;143(5):879-881.

28. Liu X, Solebo AL, Faes L, et al. Instrument-based Tests for Measuring Anterior Chamber Cells in Uveitis: A Systematic Review. Ocular Immunology and Inflammation. 2019:1-12. doi:10.1080/09273948.2019.1640883 
Figure 1. PRISMA flow diagram

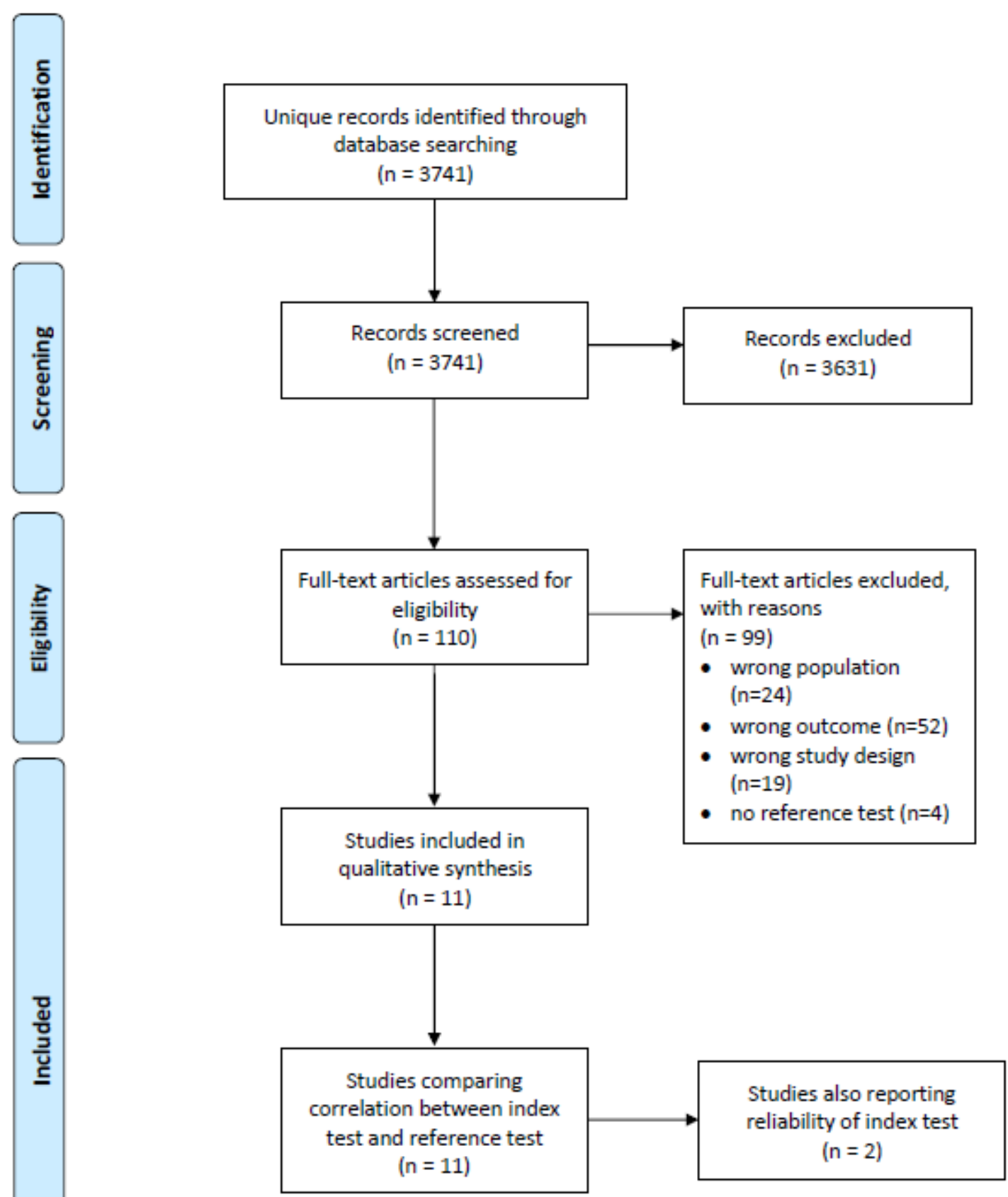


Figure 2. Level of correlation between LFP and clinician grading and aqueous protein concentration

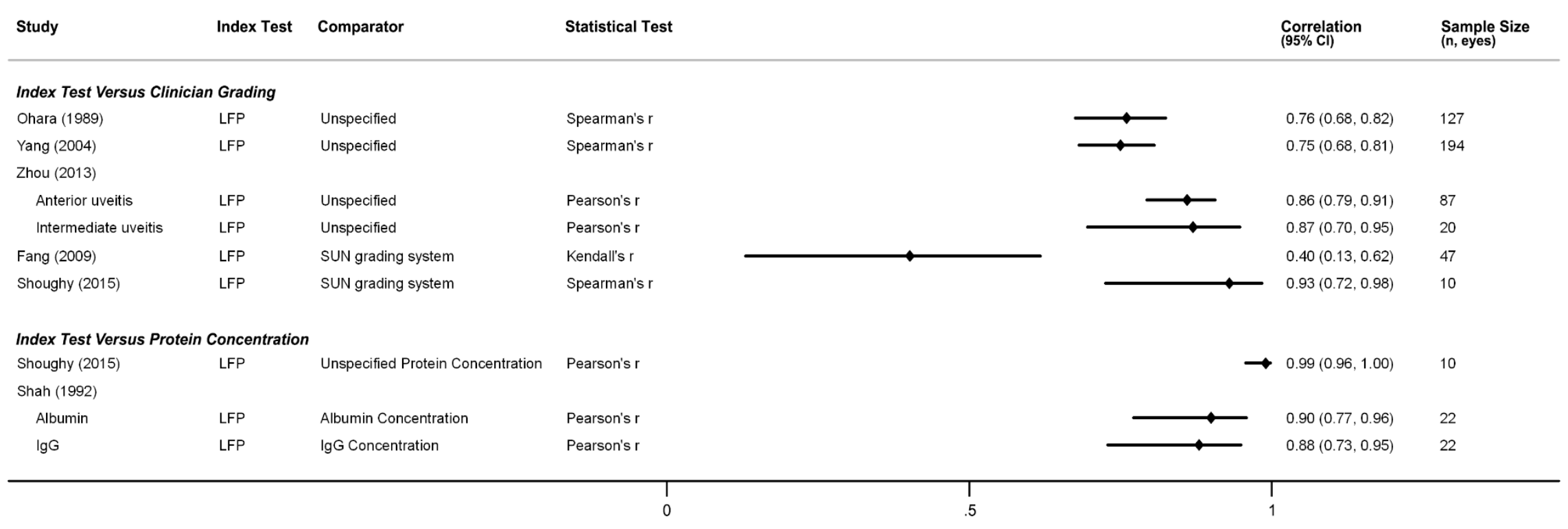


Table 1. Study Characteristics

\begin{tabular}{|c|c|c|c|c|c|c|c|}
\hline Author & Index test & $\begin{array}{l}\text { Data } \\
\text { Collection }\end{array}$ & $\begin{array}{l}\text { No. of } \\
\text { subjects }\end{array}$ & No. of eyes & Gender (\%) & Age, years & Aetiological classification, no. of eyes (\%) \\
\hline Ohara (1989) & LFP & Prospective & 124 & NR & $\begin{array}{l}44(35 \%) \text { male } \\
80(65 \%) \text { female }\end{array}$ & $\begin{array}{l}\text { NR } \\
\text { (range 12-76) }\end{array}$ & $\begin{array}{l}\text { Sarcoidosis } 53 \text { (43\%), Behcet's disease } 14 \text { (11\%), } \\
\text { VKH } 6(5 \%) \text {, ARN } 3(2 \%) \text {, Other } 14 \text { (11\%), Unknown } \\
34(27 \%)\end{array}$ \\
\hline Chiou (1998) & LFP & Prospective & 17 & 17 & NR & NR & $\begin{array}{l}\text { ARN } 5(29 \%) \text {, Lyme disease } 4(23 \%) \text {, Progressive } \\
\text { outer retinal necrosis } 2(12 \%) \text {, Anterior uveitis } 1 \\
(6 \%) \text {, Panuveitis } 1(6 \%) \text {, Retinal vasculitis } 1(6 \%) \text {, } \\
\text { HZO } 1(6 \%) \text {, FHC } 1(6 \%) \text {, Behcet's disease } 1(6 \%)\end{array}$ \\
\hline Shah (1992) & LFP & Prospective & 22 & 22 & NR & $\begin{array}{l}\text { Mean age: } \\
\text { Normal } 71 \text { (SD 10) } \\
\text { FHC } 53 \text { (SD 7) } \\
\text { Uveitis } 68 \text { (SD 6) }\end{array}$ & $\begin{array}{l}\text { FHC } 5(22.5 \%) \text {, Non-uveitic eyes undergoing } \\
\text { routine cataract surgery } 12(55 \%) \text {, Chronic uveitis } \\
\text { undergoing cataract/glaucoma surgery } 5(22.5 \%)\end{array}$ \\
\hline Yang (2004) & LFP & Prospective & 162 & $\begin{array}{l}\text { Uveitis (194) } \\
\text { Healthy eyes (52) }\end{array}$ & $\begin{array}{l}57(52 \%) \text { male } \\
53(48 \%) \text { female }\end{array}$ & $\begin{array}{l}\text { Mean 35 } \\
\text { (range 3-66) }\end{array}$ & $\begin{array}{l}\text { Anterior uveal inflammation } 110 \text { (68\%), healthy } \\
\text { controls } 52(32 \%)\end{array}$ \\
\hline Fang (2009) & LFP & Retrospective & 40 & 47 & $\begin{array}{l}15(38 \%) \text { male } \\
25(62 \%) \text { female }\end{array}$ & $\begin{array}{l}\text { Mean } 34 \\
\text { (SD 10.1) }\end{array}$ & FHC $47(100 \%)$ \\
\hline Zhou (2013) & LFP & Prospective & 129 & 171 & $\begin{array}{l}68(53 \%) \text { male } \\
61(47 \%) \text { female }\end{array}$ & $\begin{array}{l}\text { Mean } 42 \\
\text { (range 14-66) }\end{array}$ & $\begin{array}{l}\text { Anterior uveitis } 87 \text { (51\%), Intermediate uveitis } 20 \\
(12 \%) \text {, Posterior uveitis } 64(37 \%)\end{array}$ \\
\hline $\begin{array}{l}\text { Konstantopolou } \\
\text { (2015) }\end{array}$ & LFP & Prospective & 75 & 110 & $\begin{array}{l}23(31 \%) \text { male } \\
52(69 \%) \text { female }\end{array}$ & $\begin{array}{l}\text { Median } 42 \\
\text { (IQR 31-54) }\end{array}$ & NR \\
\hline Shoughy (2015) & LFP & Prospective & 20 & 20 & $\begin{array}{l}13(65 \%) \text { male } \\
7(35 \%) \text { female }\end{array}$ & $\begin{array}{l}\text { Mean } 52 \\
\text { (range 17-86) }\end{array}$ & $\begin{array}{l}\text { Anterior non-granulomatous uveitis } 5(25 \%) \text {, VKH } 4 \\
(20 \%) \text {, FHC } 1(5 \%) \text {, Non-uveitis } 10(50 \%)\end{array}$ \\
\hline $\begin{array}{l}\text { Invernizzi } \\
\text { (2017) }\end{array}$ & $\begin{array}{l}\text { LFP } \\
\text { OCT }\end{array}$ & Prospective & 122 & 237 & $\begin{array}{l}102(43 \%) \text { male } \\
135(57 \%) \text { female }\end{array}$ & $\begin{array}{l}\text { Mean age: } \\
\text { Control } 42 \text { (SD 14) } \\
\text { Inactive uveitis } 43 \text { (SD 19) } \\
\text { Active uveitis } 45 \text { (SD 22) }\end{array}$ & $\begin{array}{l}\text { Healthy control } 70(30 \%) \text {, inactive uveitis } 97(40 \%) \text {, } \\
\text { active uveitis } 70(30 \%)\end{array}$ \\
\hline Lam (2015) & OFAM & Prospective & 121 & 90 & $\begin{array}{l}38(42 \%) \text { male } \\
52(58 \%) \text { female }\end{array}$ & $\begin{array}{l}\text { Mean age: } \\
\text { Active uveitis } 44 \\
\text { No uveitis } 46\end{array}$ & NR \\
\hline $\begin{array}{l}\text { Nanavaty } \\
\text { (2011) }\end{array}$ & $\begin{array}{l}\text { Double- } \\
\text { pass } \\
\text { technique }\end{array}$ & Prospective & 44 & 56 & NR & NR & $\begin{array}{l}\text { Anterior uveitis } 24(43 \%) \\
\text { Intermediate uveitis } 9(16 \%) \\
\text { Posterior uveitis } 10(18 \%) \\
\text { Panuveitis } 13(23 \%)\end{array}$ \\
\hline
\end{tabular}

NR: not reported, OFAM: ocular flare analysis meter, OCT: optical coherence tomography, LFP: laser flare photometry, FHC: Fuch's heterochromic cyclitis. ARN: acute retinal necrosis, VKH: Vogt Koyanagi Harada disease, JIA: juvenile idiopathic arthritis, CMV: cytomegalovirus, HZO: herpes zoster ophthalmicus, *includes repeat visits of same eye. 
Table 1 continued. Index test characteristics

\begin{tabular}{|c|c|c|c|c|c|}
\hline Author & $\begin{array}{l}\text { Index } \\
\text { test }\end{array}$ & Manufacturer and model & Image acquisition settings & Area/volume & Image analysis software \\
\hline Ohara (1989) & LFP & Kowa FC-1000 & An average of 5 readings taken through dilated pupil & Per $0.075 \mathrm{~mm}^{3}$ & Built in software only \\
\hline Chiou (1998) & LFP & Kowa FC-1000 & NR & Per $0.075 \mathrm{~mm}^{3}$ & Built in software only \\
\hline Shah (1992) & LFP & Kowa FC-1000 & $\begin{array}{l}5 \text { averaged measurements } \\
\text { Measurements where BG reading }>15 \% \text { was discarded, }\end{array}$ & $0.3 \times 0.5 \mathrm{~mm}$ & Built in software only \\
\hline Yang (2004) & LFP & Kowa FC-2000 & 5 averaged measurements taken per eye & $0.3 \times 0.5 \mathrm{~mm}$ & Built in software only \\
\hline Fang (2009) & LFP & Kowa FC-2000 & $\begin{array}{l}\text { An average of } 3 \text { measurements. Measurements with } \\
\text { artefacts are discarded. }\end{array}$ & $0.3 \times 0.5 \mathrm{~mm}$ & Built in software only \\
\hline Zhou (2013) & LFP & Kowa FM-600 & $\begin{array}{l}7 \text { consecutive measurements taken, highest and lowest } \\
\text { values discarded, and remaining measurements } \\
\text { averaged. }\end{array}$ & $0.3 \times 0.5 \mathrm{~mm}$ & Built in software only \\
\hline $\begin{array}{l}\text { Konstantopolou } \\
\text { (2015) }\end{array}$ & LFP & Kowa FC-500 & $\begin{array}{l}7 \text { measurements are acquired. The highest and lowest } \\
\text { values are discarded, and remaining measurements } \\
\text { averaged. }\end{array}$ & NR & Built in software only \\
\hline \multirow[t]{2}{*}{ Shoughy (2015) } & LFP & $\begin{array}{l}\text { Laser flare photometry } \\
\text { (model NR) }\end{array}$ & NR & NR & NR \\
\hline & LFP & Kowa FM-700 & 7 averaged consecutive measurements & $0.3 \times 0.5 \mathrm{~mm}$ & Built in software only \\
\hline Invernizzi (2017) & OCT & $\begin{array}{l}\text { Casia SS-1000 OCT device } \\
\text { (Tomey Corporation, } \\
\text { Nagoya, Japan) }\end{array}$ & Two $6 \mathrm{~mm}$ line scans, each consisting of 2048 A scans. & $\begin{array}{l}200 \times 200 \text { pixel } \\
\text { area }\end{array}$ & $\begin{array}{l}\text { Custom software. A ratio of brightness } \\
\text { value between aqueous and air anterior to } \\
\text { the cornea is derived to produce an } \\
\text { aqueous-to-air relative intensity. }\end{array}$ \\
\hline Lam (2015) & OFAM & Custom OFAM device & Single measurement on an undilated eye & NR & Custom software \\
\hline Nanavaty (2011) & $\begin{array}{l}\text { Double } \\
\text {-pass } \\
\text { techniq } \\
\text { ue }\end{array}$ & $\begin{array}{l}\text { The Optical Quality } \\
\text { Analysis System (OQAS II; } \\
\text { Visionmetrics, Terrassa, } \\
\text { Spain) }\end{array}$ & 3 averaged measurements taken from dilated pupils. & NR & Built in software only \\
\hline
\end{tabular}

NR: not reported, OFAM: ocular flare analysis meter, OCT: optical coherence tomography, LFP: laser flare photometry 
Table 1 continued. Index test versus reference tests

\begin{tabular}{|c|c|c|c|c|c|c|c|c|}
\hline Author & $\begin{array}{l}\text { Index } \\
\text { test }\end{array}$ & $\begin{array}{l}\text { Clinical } \\
\text { Grading } \\
\text { System }\end{array}$ & $\begin{array}{l}\text { Manufacturer } \\
\text { and model }\end{array}$ & Observers & No. eyes in each clinical grade & $\begin{array}{l}\text { No. eyes } \\
\text { included in } \\
\text { correlation } \\
\text { analysis }\end{array}$ & $\begin{array}{l}\text { Statistical } \\
\text { Test }\end{array}$ & $\begin{array}{l}\text { Correlation } \\
\text { Coefficient } \\
(95 \% \mathrm{Cl})\end{array}$ \\
\hline Ohara (1989) & LFP & NR & Kowa FC-1000 & $\begin{array}{l}\text { One observer for all clinical } \\
\text { assessments }\end{array}$ & NR & 127 & Spearman $r$ & 0.76 \\
\hline Yang (2004) & LFP & NR & Kowa FC-2000 & NR & $\begin{array}{l}\text { Grade 0, 74; Grade 1, 98; Grade } 2 \text { 18; } \\
\text { Grade 3, 2; Grade 4, } 2\end{array}$ & 194 & Spearman $r$ & 0.75 \\
\hline Fang (2009) & LFP & SUN & Kowa FC-2000 & $\begin{array}{l}\text { One observer for all clinical } \\
\text { assessments }\end{array}$ & $\begin{array}{l}\text { Only grade } 0.5 \text { and grade } 1 \text { eyes were } \\
\text { included }\end{array}$ & 47 & Kendall $r$ & 0.40 \\
\hline Zhou (2013) & LFP & NR & Kowa FM-600 & NR & $\begin{array}{l}\text { Anterior uveitis } \\
\text { Grade } 1,48 ; \text { Grade 2, 35; Grade 3, 2; } \\
\text { Grade 4, } 2 \\
\text { Intermediate uveitis } \\
\text { Grade 1, 10; Grade 2, } 10\end{array}$ & $\begin{array}{l}87 \text { (anterior } \\
\text { uveitis) } \\
20 \\
\text { (intermedia } \\
\text { te uveitis) }\end{array}$ & Pearson $r$ & $\begin{array}{l}0.86 \\
\text { (anterior) } \\
0.87 \\
\text { (intermediate } \\
\text { group) }\end{array}$ \\
\hline $\begin{array}{l}\text { Konstantopolou } \\
\text { (2015) }\end{array}$ & LFP & SUN & Kowa FC-500 & $\begin{array}{l}\text { Two observers independently } \\
\text { performed clinical grading }\end{array}$ & $\begin{array}{l}\text { Grade 0, 5; Grade 1, 74; Grade 2, 29; } \\
\text { Grade 3, 2; Grade 4, } 0\end{array}$ & 110 & NR & NR \\
\hline Shoughy (2015) & LFP & SUN & $\begin{array}{l}\text { Laser flare } \\
\text { photometry } \\
\text { (model NR) }\end{array}$ & $\begin{array}{l}\text { Two observers independently } \\
\text { performed clinical grading }\end{array}$ & $\begin{array}{l}\text { Grade } 0,5 ; \text { Grade } 1,3 ; \text { Grade 2, 1; } \\
\text { Grade 3, 1; Grade 4, } 0\end{array}$ & 10 & Spearman $r$ & 0.93 \\
\hline \multirow{2}{*}{$\begin{array}{l}\text { Invernizzi } \\
\text { (2017) }\end{array}$} & OCT & SUN & $\begin{array}{l}\text { Casia SS-1000 } \\
\text { OCT device }\end{array}$ & NR & $\begin{array}{l}\text { Grade 0, 32; Grade 1, 21; Grade 2, 15; } \\
\text { Grade 3, } 2\end{array}$ & 70 & NR & NR \\
\hline & LFP & SUN & Kowa FM700 & NR & $\begin{array}{l}\text { Grade 0, 32; Grade 1, 21; Grade 2, 15; } \\
\text { Grade 3, } 2\end{array}$ & 70 & NR & $\mathrm{nr}$ \\
\hline Lam (2015) & OFAM & SUN & $\begin{array}{l}\text { Custom OFAM } \\
\text { device }\end{array}$ & $\begin{array}{l}\text { One observer for all clinical } \\
\text { assessments }\end{array}$ & NR & NR & NR & NR \\
\hline $\begin{array}{l}\text { Nanavaty } \\
\text { (2011) }\end{array}$ & $\begin{array}{l}\text { Doubl } \\
\text { e-pass } \\
\text { techni } \\
\text { que }\end{array}$ & SUN & $\begin{array}{l}\text { The Optical } \\
\text { Quality Analysis } \\
\text { System }\end{array}$ & $\begin{array}{l}\text { Two independent observers } \\
\text { for clinical assessment } \\
\text { Double-pass technique by a } \\
\text { technician who was blinded } \\
\text { to clinical assessment }\end{array}$ & NR & 56 & Pearson $r^{2}$ & 0.0048 \\
\hline
\end{tabular}

NR: not reported, OFAM: ocular flare analysis meter, OCT: optical coherence tomography, LFP: laser flare photometry, ARI: aqueous-to-air relative intensity [ARI] index, CC: correlation coefficient, *(including repeat visits of same eye) 
Table 1 continued. Index test versus aqueous protein concentration

\begin{tabular}{|c|c|c|c|c|c|c|c|}
\hline Author & Index test & $\begin{array}{l}\text { Protein concentration } \\
\text { test }\end{array}$ & $\begin{array}{l}\text { Proteins } \\
\text { measured }\end{array}$ & Protein concentration range & $\begin{array}{l}\text { No. eyes included in } \\
\text { correlation analysis }\end{array}$ & $\begin{array}{l}\text { Statistical } \\
\text { Test }\end{array}$ & $\begin{array}{l}\text { Correlation } \\
\text { Coefficient (95\% } \\
\text { Cl) }\end{array}$ \\
\hline Chiou & $\begin{array}{l}\text { Kowa FC- } \\
1000 \text { LFCP }\end{array}$ & Diagnostic paracentesis & $\begin{array}{l}\text { IgG } \\
\text { Albumin }\end{array}$ & NR & $\begin{array}{l}17 \text { (IgG) } \\
10 \text { (albumin) }\end{array}$ & NR & $\begin{array}{l}0.87 \text { (IgG) } \\
0.94 \text { (albumin) }\end{array}$ \\
\hline Shah & $\begin{array}{l}\text { Kowa FC- } \\
1000 \text { LFCP }\end{array}$ & $\begin{array}{l}\text { Paracentesis before } \\
\text { routine cataract surgery }\end{array}$ & $\begin{array}{l}\text { Total protein } \\
\text { Albumin } \\
\text { IgG }\end{array}$ & $\begin{array}{l}\text { Normal IgG } 0.3-4 \mathrm{mg} / \mathrm{dl} \\
\text { Normal Alb } 3.1-14 \mathrm{mg} / \mathrm{dl} \\
\text { Normal Total protein } 14-45 \mathrm{mg} / \mathrm{dl} \\
\text { FHC IgG }<2-8 \mathrm{mg} / \mathrm{dl} \\
\text { FHC Alb } 6-36 \mathrm{mg} / \mathrm{dl} \\
\text { FHCs Total protein } 14-51 \mathrm{mg} / \mathrm{dl} \\
\text { Uveitis IgG 6-50mg/dl } \\
\text { Uveitis Alb } 48-290 \mathrm{mg} / \mathrm{dl} \\
\text { Uveitis Total protein } 62-388 \mathrm{mg} / \mathrm{dl}\end{array}$ & 22 & Pearson $r$ & $\begin{array}{l}0.90 \text { (albumin) } \\
0.88 \text { (IgG) }\end{array}$ \\
\hline Shoughy & $\begin{array}{l}\text { LFP (Model } \\
\text { NR) }\end{array}$ & $\begin{array}{l}\text { Paracentesis before } \\
\text { routine cataract surgery }\end{array}$ & NR & $\begin{array}{l}\text { Normal } 10-35.48 \mathrm{mg} / \mathrm{dl} \\
\text { Anterior non-granulomatous uveitis, } 10-1490 \\
\mathrm{mg} / \mathrm{dl} \\
\mathrm{FHC}, 23.95 \mathrm{mg} / \mathrm{dl}^{*} \\
\text { VKH, } 30-600 \mathrm{mg} / \mathrm{dl}\end{array}$ & 10 & Pearson $r$ & 0.99 \\
\hline
\end{tabular}

NR: not reported, LFP: laser flare photometry, CC: correlation coefficient, FHC: Fuch's heterochromic cyclitis, VKH: Vogt Koyanagi Harada syndrome *one subject only 